\title{
Effects of Different Sources of Nitrogen on Endophytic Colonization of Rice Plants by Azospirillum sp. B510
}

\author{
KAMRUN NAHER $^{1}$, HiROKI MiwA ${ }^{1}$, SHIN OKAZAKI ${ }^{1}$, and MiCHIKO YASUdA ${ }^{1}$ \\ ${ }^{1}$ Biological Production Science, Graduate School of Agriculture, Tokyo University of Agriculture and Technology, 3-5-8 Saiwai-cho, \\ Fuchu, Tokyo 183-8509, Japan
}

(Received November 24, 2017-Accepted June 12, 2018 - Published online August 29, 2018)

Azospirillum sp. B510, a free-living nitrogen-fixing bacterium isolated from the stems of rice (Oryza sativa cv. Nipponbare), was investigated to establish effective conditions for the colonization of rice plants. We analyzed the effects of the nitrogen sources $\mathrm{KNO}_{3}, \mathrm{NH}_{4} \mathrm{Cl}$, urea $\left(\mathrm{CO}\left[\mathrm{NH}_{2}\right]_{2}\right)$, and $\mathrm{NH}_{4} \mathrm{NO}_{3}$ at different concentrations $(0.01-10 \mathrm{mM})$ on this colonization. Nitrogen promoted plant growth in a concentration-dependent manner, with minor differences being observed among the different nitrogen sources. Bacterial colonization was markedly suppressed on media containing $\mathrm{NH}_{4}{ }^{+}$concentrations higher than $1 \mathrm{mM}$. Since concentrations of up to and including $10 \mathrm{mM} \mathrm{NH}_{4}{ }^{+}$did not exhibit any antibacterial activity, we analyzed several factors affecting the $\mathrm{NH}_{4}{ }^{+}$-dependent inhibition of endophytic colonization, including the accumulation of the reactive oxygen species $\mathrm{H}_{2} \mathrm{O}_{2}$ and the secretion of the chemotactic substrate malic acid. The accumulation of $\mathrm{H}_{2} \mathrm{O}_{2}$ was increased in rice roots grown on $1 \mathrm{mM} \mathrm{NH}_{4} \mathrm{Cl}$. The amounts of malic acid secreted from $\mathrm{NH}_{4}$-grown rice plants were lower than those secreted from plants grown without nitrogen or with $\mathrm{KNO}_{3}$. Although the bacterium exhibited chemotactic activity, moving towards root exudates from plants grown without nitrogen and $\mathrm{KNO}_{3}$-grown plants, this activity was not observed with root exudates from $\mathrm{NH}_{4}^{+}-$ grown plants. $\mathrm{NH}_{4}^{+}$, but not $\mathrm{NO}_{3}^{-}$, caused the acidification of growth media, which inhibited plant bacterial colonization. These $\mathrm{NH}_{4}{ }^{+}$-dependent phenomena were markedly suppressed by the stabilization of medium pH using a buffer. These results demonstrate that the type and concentration of nitrogen fertilizer affects the colonization of rice plants by Azospirillum sp. B510.

Key words: Azospirillum sp. B510, rice, endophytic colonization, nitrogen, acidification

Biofertilizers have been widely used in many countries as an alternative to chemical fertilizers in order to increase soil fertility and crop production for sustainable farming. The application of beneficial microbes can enhance plant growth and resistance to adverse environmental stresses, such as water and nutrient deficiencies and heavy metal contamination. One group of these microbes is referred to as plant growth-promoting rhizobacteria (PGPR), and some are commercially used as biofertilizers $(6,37)$.

Azospirillum sp., a well-studied member of PGPR, has been found in association with some of the world's most staple food crops, including rice, maize, sorghum, wheat, and millet (14, 19, 28, 34). Members of the genus Azospirillum are widespread in soil and their inoculation on cereals and forage crops results in yield increases in many field experiments, not only due to nitrogen fixation, but also through the production of plant growth-promoting substances, such as the phytohormones indole- 3 acetic acid (IAA) and gibberellic acid $(2,22)$. The inoculation of $A$. brasilense into Zea mays and Sorghum biocolor has been reported to enhance the uptake of mineral ions $\left(\mathrm{NO}_{3}{ }^{-}\right.$, $\mathrm{K}^{+}$, and $\mathrm{H}_{2} \mathrm{PO}_{4}^{-}$) (28). The uptake of $\mathrm{NH}_{4}{ }^{+}$and $\mathrm{PO}_{4}^{-}$was also enhanced in rice plants after an inoculation with $A$. lipoferum under hydroponic conditions (31).

Azospirillum sp. B510 (B510) is a diazotrophic endophyte that has been isolated from the stems of a rice plant (Oryza sativa cv. Nipponbare) (13). Increased seed production by B510-colonized rice plants was demonstrated under greenhouse, paddy field, and laboratory conditions (7, 21, 37). Moreover,

\footnotetext{
* Corresponding author. E-mail: ysdmichi@cc.tuat.ac.jp;
} Tel: +81-42-367-5847; Fax: +81-42-367-5847. rice plants inoculated with this bacterium had induced resistance against rice blast disease and rice blight disease (42). Kaneko et al. (23) determined the complete genome sequence of B510; it has a single chromosome and six plasmids encoding 3,416 putative proteins, including putative genes encoding enzymes related to IAA biosynthesis and the reduction of host ethylene levels. A comparative metabolomic analysis revealed that rice plants inoculated with B510 induced a modified metabolic response in shoots and roots, suggesting that this bacterium triggers a systemic response against pathogens (7). Consequently, the beneficial effects of B510 colonization in rice make it a useful biofertilizer. However, these beneficial effects were found to vary in field experiments, depending on both the rice genotype and nitrogen level (37). Moreover, neither the mechanism by which this bacterium colonizes host plants nor the relationship between colonization and environmental conditions around the roots has been elucidated.

Nitrogen fertilizers, particularly ammonium, the form of nitrogen favored by rice, are widely used in rice cultivation; however, the influence of nitrogen fertilizers on the establishment of endophytic colonization by bacteria, such as B510, has not yet been clarified. Thus, to understand the relationship between nitrogen nutrition and endophytic colonization by $\mathrm{B} 510$ in rice plants, we performed physiological, histochemical, and microscopic analyses on rice-Azospirillum interactions. We found that high concentrations of $\mathrm{NH}_{4}{ }^{+}$exert indirect suppressive effects on the colonization of rice plants by B510. We also propose a model to explain the mechanisms responsible for the effects of high $\mathrm{NH}_{4}{ }^{+}$concentrations on the plant redox state, rhizosphere acidification, bacterial chemotaxis, and host colonization by B510. 


\section{Materials and Methods}

\section{Bacterial strains and growth conditions}

The bacterial strains used in the present study are listed in Table S1. Azospirillum sp. B510 was grown at $28^{\circ} \mathrm{C}$ in nutrient broth (NB) medium (Eiken Chemical, Tokyo, Japan) with appropriate antibiotics (50 $\mu \mathrm{g} \mathrm{mL}^{-1}$ polymyxin and $50 \mu \mathrm{g} \mathrm{mL}^{-1}$ streptomycin). Escherichia coli strain $\mathrm{S} 17-1$ was grown at $37^{\circ} \mathrm{C}$ in Luria-Bertani (LB) medium supplemented with $50 \mu \mathrm{g} \mathrm{mL}^{-1}$ ampicillin. DsRed-labeled Azospirillum sp. B510 was constructed using the plasmid pBjGroEL4::DsRed2, as described by Hayashi et al. (18).

\section{Plant growth conditions and endophytic inoculation}

Seed coats were removed from rice seeds (O. sativa cv. Nipponbare), which were then surface-sterilized with $70 \%$ ethanol for $30 \mathrm{~s}$ and shaken in 5\% (w/v) sodium hypochlorite (Wako Pure Chemical Industries, Osaka, Japan) for $10 \mathrm{~min}$. Seeds were then washed with sterilized distilled water three times for $10 \mathrm{~min}$ each time.

Regarding seed inoculation, B510 was grown on NB medium including $50 \mathrm{mg} \mathrm{L}^{-1}$ polymyxin B (Wako Pure Chemical Industries) at $28^{\circ} \mathrm{C}$, harvested at $30 \mathrm{~h}$, and washed twice with sterilized distilled water. Bacterial cells were resuspended in sterilized distilled water to a final density of $10^{9}$ colony-forming units (CFU) $\mathrm{mL}^{-1}$ $\left(\mathrm{OD}_{600}=1.0\right)$. Bacterial suspensions were diluted 100 -fold in sterilized distilled water to a final density of $2 \times 10^{7} \mathrm{CFU} \mathrm{mL}^{-1}$.

Sterilized seeds were transferred into plant boxes containing $100 \mathrm{~mL}$ of semisolid rice growth (RG) medium adjusted to $\mathrm{pH} 5.5$ (13) with various concentrations of nitrogen and were immediately inoculated with B510 $\left(50 \mu \mathrm{L}\right.$ seed $\left.{ }^{-1}\right)$. Potassium nitrate $\left(\mathrm{KNO}_{3}\right)$, ammonium chloride $\left(\mathrm{NH}_{4} \mathrm{Cl}\right)$, urea $\left(\mathrm{CO}\left[\mathrm{NH}_{2}\right]_{2}\right)$, and ammonium nitrate $\left(\mathrm{NH}_{4} \mathrm{NO}_{3}\right)$ were obtained from Wako Pure Chemical Industries and the absence of a nitrogen source acted as a control. Stock solutions (prepared in distilled water at a concentration of $1 \mathrm{M}$ ) were then filtered through a $0.22-\mu \mathrm{m}$ membrane filter (Millex-GP; Merck Millipore, Damstadt, Germany). Plant boxes (CUL-JAR300; Iwaki, Tokyo, Japan) containing the inoculated seeds were incubated in a plant growth chamber (LPH-240SP; NK System, Osaka, Japan) under 16-h light:8-h dark conditions at $25^{\circ} \mathrm{C}$ for $7-10 \mathrm{~d}$ depending on the individual experiment.

\section{Estimation of the population of Azospirillum sp. B510 inside rice tissues}

To estimate the population of B510 inside rice tissues, whole 10-d-old seedlings of $O$. sativa cv. Nipponbare previously inoculated with the bacteria were weighed and then surface-sterilized with $70 \%$ ethanol for $15 \mathrm{~s}$ and subsequently with $1 \%$ sodium hypochlorite $(\mathrm{NaOCl})$ for $30 \mathrm{~s}$. The seedlings were then quickly washed five times with sterilized distilled water. The seedlings were homogenized in $0.8 \% \mathrm{NaCl}$ using a sterilized mortar and pestle and the homogenate was plated on NB agar containing $50 \mathrm{mg} \mathrm{L}^{-1}$ polymyxin $\mathrm{B}$ at appropriate dilutions. After an incubation at $28^{\circ} \mathrm{C}$ for $3 \mathrm{~d}$, the number of polymyxin B-resistant bacterial colonies was counted.

\section{Microscopy}

Regarding fluorescence microscopy, rice seedlings inoculated with DsRed-labeled Azospirillum sp. B510 were cultivated for $10 \mathrm{~d}$, sampled from the agar plant box, and washed gently with sterilized distilled water. The roots were placed separately on microscope slides. They were observed and photographed using an Olympus IX71 fluorescence stereomicroscope (Olympus, Tokyo, Japan). Each field was observed under three different conditions: optical light microscopy, fluorescence microscopy with a GFP field, and fluorescence microscopy with a Ds-Red field to confirm red fluorescence from DsRed-labeled Azospirillum sp. B510.

\section{$D A B$ staining}

3,3'-Diaminobenzidine (DAB) staining was performed according to the procedures described by Fester and Hause (15) with the following modifications. To visualize hydrogen peroxide $\left(\mathrm{H}_{2} \mathrm{O}_{2}\right)$, rice plants were placed in DAB solution $\left(1 \mathrm{mg} \mathrm{mL}^{-1} \mathrm{DAB}\right.$; Tokyo Chemical Industry, Tokyo, Japan) buffered with $200 \mathrm{mM}$ sodium phosphate, $\mathrm{pH} 6.5$, at room temperature for 3-4 h. Photographs were taken using a Lumix DMC-G3 camera (Panasonic, Osaka, Japan). Quantitative measurements of $\mathrm{H}_{2} \mathrm{O}_{2}$ were analyzed as described previously (43). Briefly, DAB-stained root samples (100 mg) were washed in $80 \%$ ethanol for $20 \mathrm{~min}$ and homogenized immediately in $500 \mu \mathrm{L}$ of $0.2 \mathrm{M}$ perchloric acid $\left(\mathrm{HClO}_{4}\right)$ (Wako Pure Chemical Industries) in a pre-cooled mortar. The mixtures were incubated on ice for $5 \mathrm{~min}$ and then centrifuged $\left(10,000 \times \mathrm{g}, 4^{\circ} \mathrm{C}, 10 \mathrm{~min}\right)$. The absorbance of the supernatants was measured at $450 \mathrm{~nm}$ and $\mathrm{H}_{2} \mathrm{O}_{2}$ concentrations were obtained via a standard calibration with solutions of $0.2 \mathrm{M} \mathrm{HClO}_{4}$ containing 5, 10, 25, and $50 \mu \mathrm{M} \mathrm{H}_{2} \mathrm{O}_{2}$ (SigmaAldrich, St. Louis, MO, USA).

\section{Measurement of malic acid in root exudates}

Rice plants were grown in RG medium inoculated with or without B510 for $10 \mathrm{~d}$. Each seedling was washed gently with sterilized distilled water and placed into $30 \mathrm{~mL}$ Milli-Q water in a $50-\mathrm{mL}$ Falcon ${ }^{\mathrm{TM}}$ tube for $2 \mathrm{~d}$ in the growth chamber. After the removal of seedlings, the solution was filtered with a $0.22-\mu \mathrm{m}$ membrane filter (Millex-GP; Merck Millipore), lyophilized, and stored at $-80^{\circ} \mathrm{C}$. The lyophilized sample was dissolved in $1 \mathrm{~mL}$ Milli-Q water before being analyzed.

A malic acid analysis was performed using the series LC-20AC HPLC system (Shimadzu, Kyoto, Japan) with a Shodex RSPAK $\mathrm{KC}-811(300 \times 8 \mathrm{~mm})$ analytical column and $\mathrm{KC}-811$ pre-column (Showa Denko K.K., Tokyo, Japan) run with $0.1 \%$ phosphate buffer at a flow rate of $0.25 \mathrm{~mL} \mathrm{~min}{ }^{-1}$. The column temperature was set to $40^{\circ} \mathrm{C}$. Malic acid was detected and quantified using a UV detector set at $210 \mathrm{~nm}$. The peaks obtained were compared with an array of standard malic acid peaks run under the same conditions. The major peak was identified by comparing the retention time with that of the matching standard. Standard malic acid (Sigma-Aldrich) and root exudates $(25 \mu \mathrm{L}$ of each) were sequentially injected into the chromatographic system and run under the same conditions with four replicates per sample. Malic acid in the root exudate was identified by comparisons with the retention times of standard samples.

\section{Chemotaxis assay}

The drop assay was performed as described in de Weert et al. (10) with slight modifications. B510 was grown in NB medium at $28^{\circ} \mathrm{C}$ and $160 \mathrm{rpm}$ until the logarithmic phase $\left(\mathrm{OD}_{600}\right.$ of 0.8$)$ was obtained. Bacterial cells were washed and resuspended in sterilized distilled water to an $\mathrm{OD}_{600}$ of 2.0 and $1 \%$ hydroxypropylmethylcellulose solution (Sigma-Aldrich) was then added (final concentration, $0.25 \%$ ). The cell suspension was transferred to a $90-\mathrm{mm}$ Petri dish, on which it formed a 3-mm-thick layer. Concentrated (50-fold) root exudates or individual $100 \mathrm{mM}$ organic acid components were added to the center of the dish as a $10-\mu \mathrm{L}$ drop. After an incubation at room temperature for $15 \mathrm{~min}$, the plates were inspected for the appearance of a clear zone surrounding the drop.

\section{Biofilm assay}

The production of biofilms by Azospirillum sp. B510 was measured in vitro using a PVC microtiter plate assay (40). Five $\mu \mathrm{l}$ of B510 cultures adjusted to $\mathrm{OD}_{600}=0.01$ were inoculated into $95 \mu \mathrm{L}$ of NB medium a 96-well microtiter plate (TPP Techno Plastic Products AG, Trasadingen, Switzerland), which was then incubated without shaking at $28^{\circ} \mathrm{C}$ for $48 \mathrm{~h}$. In the quantification of biofilm development, $25 \mu \mathrm{L}$ of $1.0 \%$ crystal violet solution (Wako Pure Chemical Industries) was added to the wells. After a 30-min incubation, unbound crystal violet in each well was gently removed with a pipette and the wells were washed with distilled water, followed by $70 \%$ ethanol, and then distilled water. Crystal violet in each well was solubilized by adding $100 \mu \mathrm{L}$ of $100 \%$ ethanol and quantified by absorbance at $550 \mathrm{~nm}$. 


\section{pH measurement}

The $\mathrm{pH}$ of the cultivation medium was adjusted to 5.5 before cultivation. After cultivation for $7 \mathrm{~d}, \mathrm{RG}$ medium was removed from the plants and mixed thoroughly. The $\mathrm{pH}$ of the medium was measured using a pH meter (Horiba, Kyoto, Japan). RG medium containing $0.05 \%$ bromophenol blue (BPB, Wako Pure Chemical Industries) was used to assess $\mathrm{pH}$. To maintain $\mathrm{pH}$ in $\mathrm{RG}$ medium at $5.5,100 \mathrm{mM}$ of 2-morpholinoethanesulfonic acid monohydrate (MES) (Wako Pure Chemical Industries) was added to $\mathrm{RG}$ medium containing $\mathrm{NH}_{4} \mathrm{Cl}$.

\section{Statistical analysis}

Statistical analyses were performed using a one-way analysis of variance (ANOVA) followed by the Student-Newman-Keuls (SNK) test. Different lower-case letters represent significantly different values $(P<0.05)$.

\section{Results}

Effects of various nitrogen sources on endophytic colonization of rice by Azospirillum sp. B510

Seedlings of $O$. sativa cv. Nipponbare were inoculated with the DsRed-labeled B510 strain to establish optimum conditions for endophytic colonization. Plants were grown in RG medium containing different concentrations $(0.01-10 \mathrm{mM})$ of each nitrogen source $\left(\mathrm{KNO}_{3}\right.$, urea, $\mathrm{NH}_{4} \mathrm{Cl}$, or $\left.\mathrm{NH}_{4} \mathrm{NO}_{3}\right)$. In most cases, rice roots inoculated with DsRed-labeled B510 showed strong red fluorescence under the fluorescence microscope (Fig. 1). Marked differences were not observed between 0.01 and $0.1 \mathrm{mM}$ of each nitrogen source. Rice plants grown in more than $1 \mathrm{mM} \mathrm{KNO}_{3}$ or urea exhibited strong fluorescence, indicating well-established bacterial colonization on root surfaces (epiphytic colonization). In contrast, red fluorescence was not detected in plants grown at $\mathrm{NH}_{4} \mathrm{Cl}$ and $\mathrm{NH}_{4} \mathrm{NO}_{3}$ concentrations

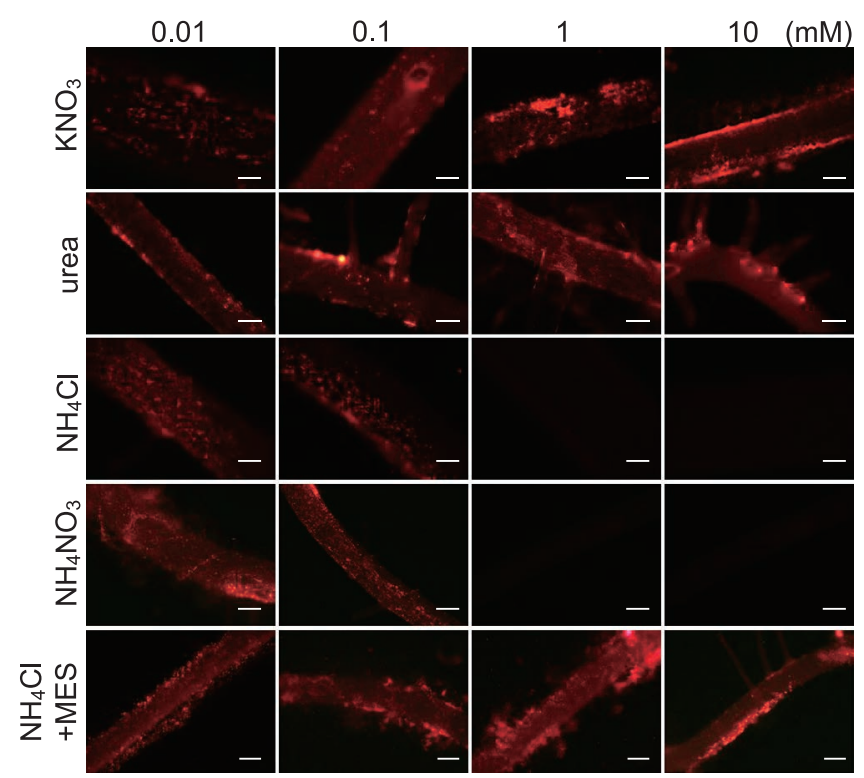

Fig. 1. Epiphytic colonization of rice roots by DsRed-labeled Azospirillum sp. B510.

Colonization by B510 was observed using fluorescence microscopy (Olympus, BX50). Micrographs of 10-d-old lateral roots grown on RG medium containing different sources and concentrations of nitrogen are as indicated. Scale bars $=100 \mu \mathrm{m}$. of $1 \mathrm{mM}$ or higher, suggesting that $\mathrm{NH}_{4}{ }^{+}$suppressed bacterial colonization (Fig. 1). To further confirm these results, we counted the number of B510 cells on root surfaces. The number of B510 cells on root surfaces was 100-fold lower in $1 \mathrm{mM}$ $\mathrm{NH}_{4}$ Cl-treated plants and 10,000-fold lower in $10 \mathrm{mM}$ $\mathrm{NH}_{4} \mathrm{Cl}$-treated plants than in control plants without $\mathrm{NH}_{4} \mathrm{Cl}$ (Fig. S1).

We then examined the endophytic colonization of rice by B510 by counting the number of colonies within surfacesterilized whole plants $10 \mathrm{~d}$ post-inoculation (Fig. 2). In rice plants grown on $\mathrm{KNO}_{3}$, the number of B510 cells became higher as the $\mathrm{KNO}_{3}$ concentration increased (Fig. 2A). Although the root length was very short in $\mathrm{RG}$ medium containing $10 \mathrm{mM}$ urea, endophytic colonization was clearly detected (Fig. 2B and S2). B510 colonized the inside of host roots with $10^{5}-10^{6} \mathrm{CFU} \mathrm{\textrm {g } ^ { - 1 }}$ fresh weight at low concentrations $(0.01-0.1 \mathrm{mM})$ of $\mathrm{NH}_{4} \mathrm{Cl}$. However, endophytic colonization by $\mathrm{B} 510$ was markedly suppressed at high concentrations (higher than $1 \mathrm{mM}$ ) of $\mathrm{NH}_{4} \mathrm{Cl}$ with no detection (Fig. 2C). B510 also colonized host roots with $10^{3}-10^{5} \mathrm{CFU} \mathrm{g}^{-1}$ fresh weight at a low $\mathrm{NH}_{4} \mathrm{NO}_{3}$ concentration $(0.01-0.1 \mathrm{mM})$, and only $10^{2} \mathrm{CFU} \mathrm{g}^{-1}$ fresh weight or no detection at 1 or $10 \mathrm{mM}$ $\mathrm{NH}_{4} \mathrm{NO}_{3}$, respectively. These results indicate that high concentrations of both forms of ammonium $\left(\mathrm{NH}_{4} \mathrm{Cl}\right.$ and $\left.\mathrm{NH}_{4} \mathrm{NO}_{3}\right)$ have a negative effect on endophytic colonization by $\mathrm{B} 510$.
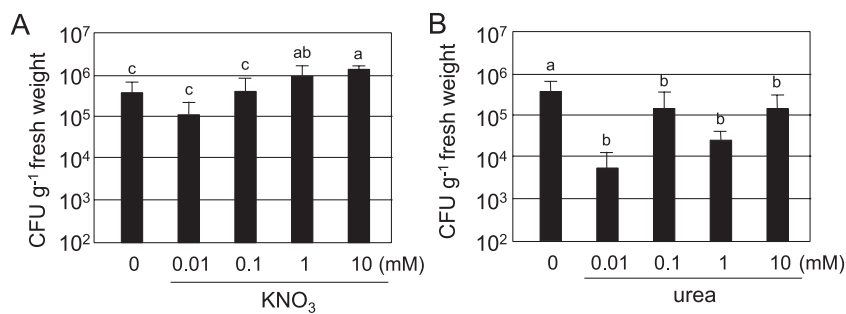

C
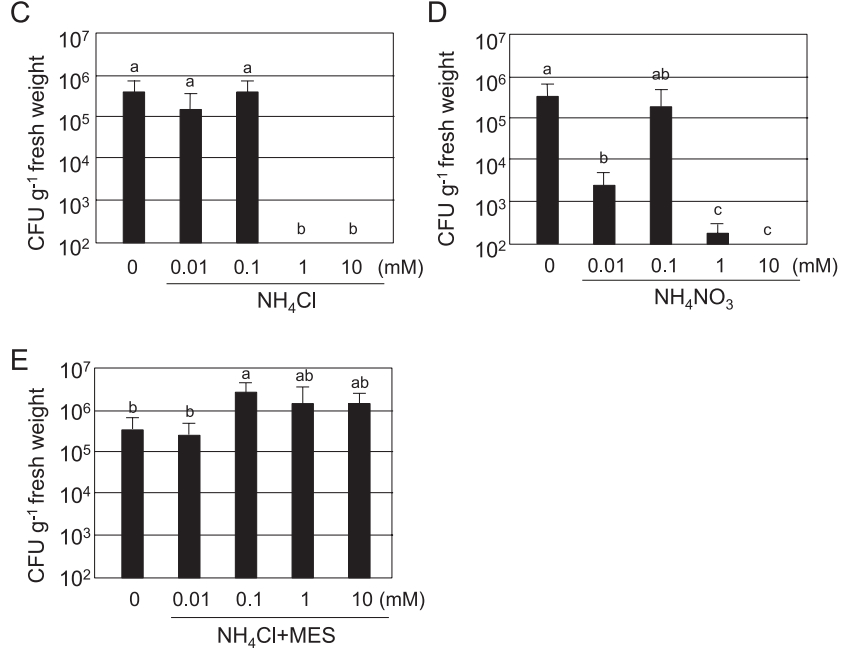

Fig. 2. Endophytic colonization of rice plants grown with different nitrogen sources by Azospirillum sp. B510.

(A) $\mathrm{KNO}_{3}$, (B) urea, (C) $\mathrm{NH}_{4} \mathrm{Cl}$, (D) $\mathrm{NH}_{4} \mathrm{NO}_{3}$, (E) $\mathrm{NH}_{4} \mathrm{Cl}+100 \mathrm{mM}$ MES buffer. Seeds were treated with B510 (final concentration, $2 \times 10^{5} \mathrm{CFU}$ plant ${ }^{-1}$ ). Whole plants were surface sterilized and homogenized $10 \mathrm{~d}$ after the inoculation. The number of CFU was estimated by their growth on nutrient broth agar plates containing $50 \mu \mathrm{M}$ polymyxin. Values presented are the average \pm SD from four replicates of one plant each. Different letters indicate significant differences between treatments (Student-Newman-Keuls [SNK] test, $P<0.05, n=4$ ). 
Since a high concentration of $\mathrm{NH}_{4}{ }^{+}$is known to have a toxic effect on bacteria $(3,29)$, we investigated whether $\mathrm{NH}_{4}^{+}$ inhibits the growth of B510 at the concentrations used in the colonization experiments. B510 was incubated in RG medium adjusted to $\mathrm{pH} 5.5$ containing each concentration $(0.01,0.1$, 1 , and $10 \mathrm{mM}$ ) of $\mathrm{NH}_{4} \mathrm{Cl}$. No significant differences were observed in bacterial growth among these concentrations of $\mathrm{NH}_{4} \mathrm{Cl}$, demonstrating that $\mathrm{NH}_{4}{ }^{+}$did not exhibit any antimicrobial activity against B510, which is in contrast to findings obtained using other bacteria (Table S3). These results indicate that endophytic colonization by B510 was inhibited by high concentrations of $\mathrm{NH}_{4}^{+}$, but also that high concentrations of $\mathrm{NH}_{4}{ }^{+}$did not inhibit B510 growth in vitro. Bacterial exopolysaccharides (EPS) are important for the attachment of the endophyte to the root surface (30). The establishment of a biofilm structure involves bacterial cells and EPS, which produce an optimal biosphere for the conversation of genetic material between cells. Thus, biofilms are of great importance in the plant-microbe interaction. The quantity of EPS in biofilms may comprise approximately 50-90\% of organic compounds (11). However, B510 produced EPS or biofilms at similar levels regardless of the nitrogen source $\left(\mathrm{NH}_{4}+\right.$ or $\mathrm{NO}_{3}$; Fig. $\mathrm{S} 4 \mathrm{~A}$ and $\mathrm{B})$. This result suggests that EPS or biofilm-mediated attachment is not a key step in the $\mathrm{NH}_{4}{ }^{+}$-dependent suppression of colonization.

\section{$\mathrm{NH}_{4} \mathrm{Cl}$ induces $\mathrm{H}_{2} \mathrm{O}_{2}$ accumulation in rice roots}

Plant-associated bacteria need to cope with host defense responses during infection. Plant defense responses to pathogen infection involve the production of reactive oxygen species (ROS), including $\mathrm{H}_{2} \mathrm{O}_{2} \cdot \mathrm{H}_{2} \mathrm{O}_{2}$ directly inhibits the growth of bacterial and fungal pathogens (41). Since infection by B510 was suppressed at $1 \mathrm{mM} \mathrm{NH}_{4}^{+}$, we measured the accumulation of $\mathrm{H}_{2} \mathrm{O}_{2}$ in the roots of infected rice plants grown without nitrogen (control) and with $1 \mathrm{mM} \mathrm{KNO}_{3}$ and $1 \mathrm{mM} \mathrm{NH}_{4} \mathrm{Cl}$ using the DAB staining method (Fig. 3). The brown color that formed with $\mathrm{DAB}$, which correlates with $\mathrm{H}_{2} \mathrm{O}_{2}$ accumulation, was more intense in roots that were grown in $\mathrm{NH}_{4} \mathrm{Cl}$ than in $\mathrm{KNO}_{3}$ and the control (Fig. 3B). Quantitative measurements of $\mathrm{H}_{2} \mathrm{O}_{2}$ revealed that $\mathrm{NH}_{4} \mathrm{Cl}$ induced significantly greater $\mathrm{H}_{2} \mathrm{O}_{2}$ accumulation than $\mathrm{KNO}_{3}$ (Fig. 3A). These results suggest that $\mathrm{H}_{2} \mathrm{O}_{2}$ accumulated with the $\mathrm{NH}_{4} \mathrm{Cl}$ treatment, but that its production was slightly reduced by the inoculation with B510.

Chemotactic responses to root exudates from plants grown with $\mathrm{KNO}_{3}$ or $\mathrm{NH}_{4} \mathrm{Cl}$

Azospirillum strains display chemotactic responses to specific substrates, such as root exudates, including organic acids (33). To analyze chemotactic responses to root exudates secreted from rice roots grown in $\mathrm{RG}$ media without nitrogen (control) and with $\mathrm{KNO}_{3}$ and $\mathrm{NH}_{4} \mathrm{Cl}$, we performed a taxis assay (Fig. 4). Root exudates extracted from control and $\mathrm{KNO}_{3}$-grown roots resulted in the formation of a bacterial ring in the plate assay, revealing a positive chemotactic reaction. However, the bacterial ring was not observed when root exudates from $\mathrm{NH}_{4} \mathrm{Cl}$-grown roots were used (Fig. 4). The bacterial rings formed by the root exudates of B510-inoculated plants were slightly larger than those of the non-inoculated control, suggesting that the B510 inoculation stimulated chemoattractant production by roots (Fig. 4, lower panels).
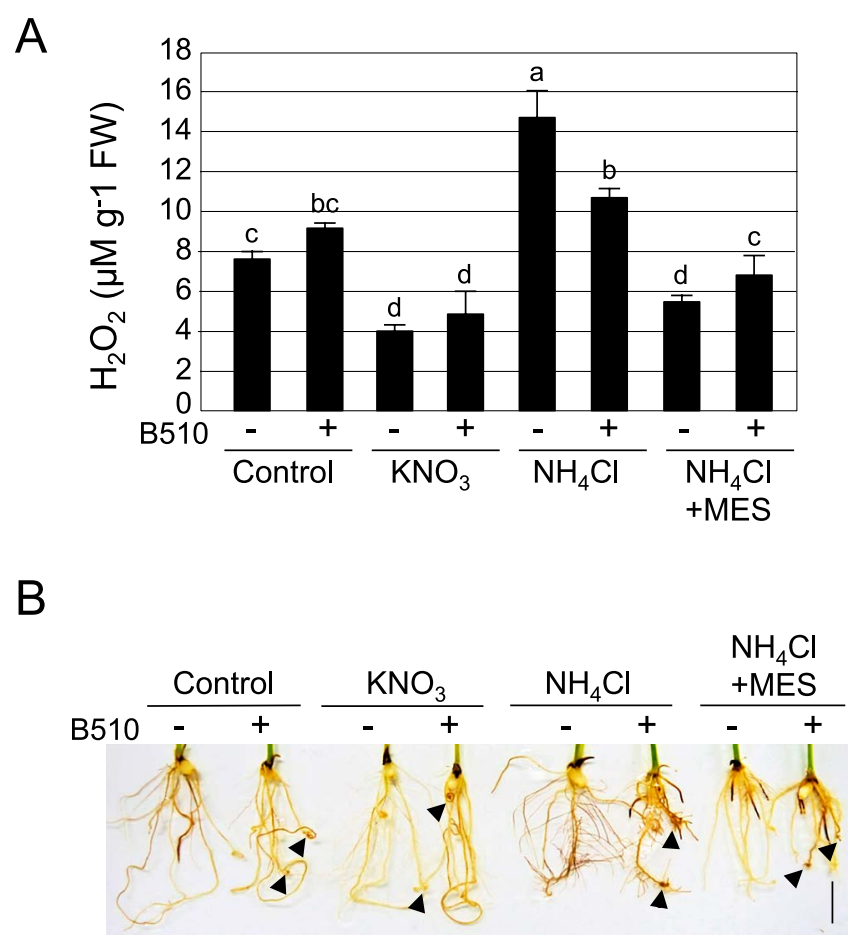

Fig. 3. Qualitative and quantitative assessments of $\mathrm{H}_{2} \mathrm{O}_{2}$ in B510inoculated rice grown on $\mathrm{RG}$ medium.

$\mathrm{DAB}$ staining was performed $10 \mathrm{~d}$ after the inoculation of rice seeds with B510. (A) The accumulation of $\mathrm{H}_{2} \mathrm{O}_{2}$ was quantified in the roots using standard $\mathrm{H}_{2} \mathrm{O}_{2}$ concentrations to calibrate data during optical density (OD) measurements. Plants were grown in $\mathrm{RG}$ medium including $1 \mathrm{mM}$ of $\mathrm{KNO}_{3}, 1 \mathrm{mM} \mathrm{NH}_{4} \mathrm{Cl}, 1 \mathrm{mM} \mathrm{NH}_{4} \mathrm{Cl}+100 \mathrm{mM}$ MES, or without nitrogen (control), inoculated with B510 (+) or not inoculated (-). Error bars indicate standard deviations $(n=3)$. (B) $\mathrm{H}_{2} \mathrm{O}_{2}$ levels correlate with color intensity (brown). The arrow indicates root curling. Scale bar $=0.5 \mathrm{~cm}$.
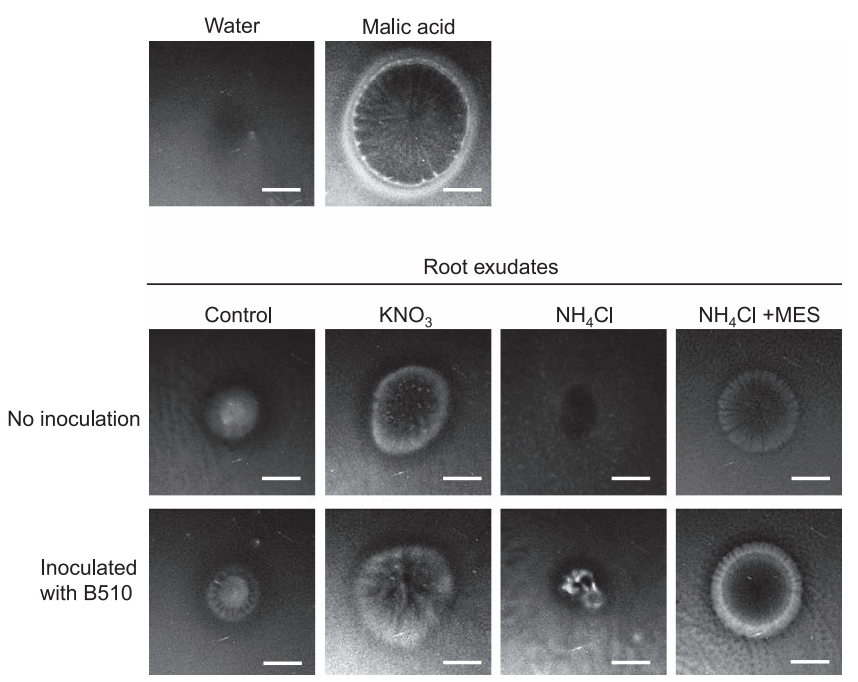

Fig. 4. Chemotactic response of B510 towards rice root exudates. The chemotactic response of B510 was analyzed using a negative control (water), positive control (100 mM Malic acid), and root exudates from rice roots. Rice seedlings were grown in $\mathrm{RG}$ media including control, $1 \mathrm{mM} \mathrm{KNO} 3,1 \mathrm{mM} \mathrm{NH}_{4} \mathrm{Cl}$, or $1 \mathrm{mM} \mathrm{NH}_{4} \mathrm{Cl}+100 \mathrm{mM} \mathrm{MES}$ for $10 \mathrm{~d}$ without an inoculation or an inoculation with $\mathrm{B} 510$. Before transplantation, seedlings were washed twice in sterilized distilled water and transplanted to $30 \mathrm{~mL}$ sterilized distilled water for $2 \mathrm{~d}$. A 50 -fold concentrated root exudate $(10 \mu \mathrm{L})$ was added to the center of each Petri dish $(90 \mathrm{~mm})$. The bacterial chemotactic response was triggered after an incubation at room temperature for $10 \mathrm{~min}$. A response correlated with the appearance of a ring of turbidity near the center of each Petri dish. Scale bars $=1 \mathrm{~cm}$. The experiment was repeated three times with similar results. 


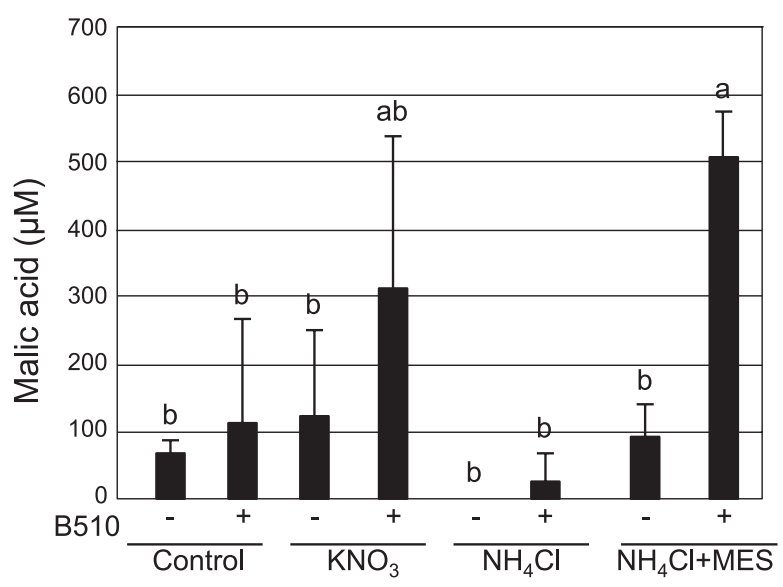

Fig. 5. Measurement of malic acid in root exudates.

Root exudates were extracted from 10-d-old seedlings grown in RG medium including $1 \mathrm{mM}$ of $\mathrm{KNO}_{3}, 1 \mathrm{mM} \mathrm{NH}_{4} \mathrm{Cl}, 1 \mathrm{mM} \mathrm{NH}_{4} \mathrm{Cl}+100 \mathrm{mM}$ MES, or without nitrogen (control) without an inoculation (-) or inoculated $(+)$ with B510. Malic acid concentrations were quantified by HPLC. The experiment was repeated three times with similar results.

Measurement of malic acid in root exudates from plants grown with $\mathrm{KNO}_{3}$ or $\mathrm{NH}_{4} \mathrm{Cl}$

Previous studies revealed that root-secreted malic acid (a chemotaxis substrate) recruits beneficial soil bacteria to promote binding and biofilm formation in Arabidopsis (35). B510 also responds to malic acid and other organic acids (Fig. S3). To investigate whether the amount of organic acids secreted by the roots increased $10 \mathrm{~d}$ after the B510 inoculation, we quantified malic acid secreted from the roots using HPLC. No significant differences were observed in the concentration of malic acid between control plants without the inoculation and B510-inoculated plants (Fig. 5). Although the amount of malic acid secreted from plants grown in $\mathrm{KNO}_{3}$ without the inoculation was similar to that of plants grown in the absence of a nitrogen source with and without the inoculation, the amount of malic acid markedly increased when the plants had also been inoculated with B510 (Fig. 5). Malic acid was not detected in the root exudates secreted from non-inoculated $\mathrm{NH}_{4} \mathrm{Cl}$-grown plants, whereas a small amount was detected in the root exudates of B510-inoculated plants grown with $\mathrm{NH}_{4} \mathrm{Cl}$ (Fig. 5). These results indicate that the B510 inoculation slightly increased the secretion of malic acid from rice roots although no significant difference was observed between inoculated and non-inoculated plants.

\section{Acidification of the rhizosphere by $\mathrm{NH}_{4}{ }^{+}$affects endophytic colonization by $B 510$}

Nitrogen plays a prominent role in the cation-anion balance. It may be taken up by plants as a cation $\left(\mathrm{NH}_{4}{ }^{+}\right)$or anion $\left(\mathrm{NO}_{3}{ }^{-}\right)$. Previous studies demonstrated that plants supplied with $\mathrm{NO}_{3}{ }^{-}$counterbalance the corresponding excess of negative charges by releasing equivalent amounts of $\mathrm{OH}^{-}$or $\mathrm{HCO}_{3}{ }^{-}$into the rhizosphere, thereby increasing rhizosphere $\mathrm{pH}(9,27)$. Plants receiving $\mathrm{NH}_{4}^{+}$counterbalance the corresponding excess of positive charges by releasing equivalent amounts of $\mathrm{H}^{+}$into the rhizosphere, thereby decreasing rhizosphere $\mathrm{pH}$ (20). Thus, we examined whether a $\mathrm{pH}$ change in the rhizosphere using different nitrogen sources affects the B510-endophytic colonization of rice plants. Before planting

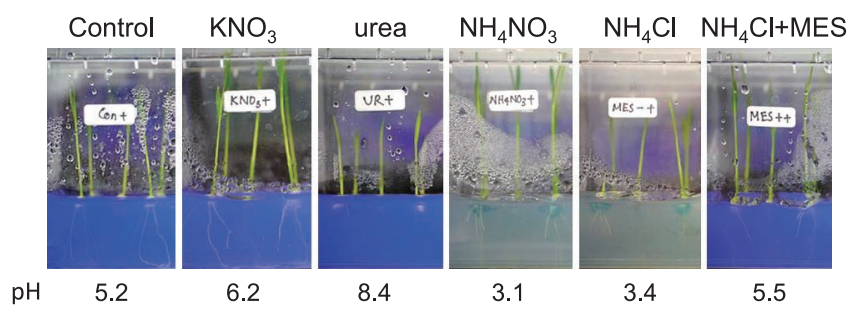

Fig. 6. Visualization of changes in $\mathrm{pH}$ in $\mathrm{RG}$ medium containing various nitrogen sources.

Rice seedlings were grown in $\mathrm{RG}$ medium containing bromophenol blue (BPB) including $1 \mathrm{mM}$ of $\mathrm{KNO}_{3}, 1 \mathrm{mM} \mathrm{NH}_{4} \mathrm{Cl}, 1 \mathrm{mM} \mathrm{NH} 4 \mathrm{Cl}+100 \mathrm{mM}$ MES, or without nitrogen (control) for $10 \mathrm{~d}$. The decolorization of BPB correlated with a decrease in $\mathrm{pH}$ levels in $\mathrm{RG}$ medium. Photos were taken $7 \mathrm{~d}$ after planting.

the seeds, the $\mathrm{pH}$ of $\mathrm{RG}$ medium was adjusted to 5.5. The acidification of RG medium after plant growth was clearly visualized using BPB, which changes from purple-blue to colorless when $\mathrm{pH}$ is between 3.0-4.6 (Fig. 6). The $\mathrm{pH}$ of control medium (without nitrogen) decreased slightly to $\mathrm{pH}$ $5.27 \mathrm{~d}$ after planting (Fig. 6). In the cases of $\mathrm{KNO}_{3}$ and urea, $\mathrm{pH}$ increased to 6.2 and 8.4, respectively. However, in the cases of $\mathrm{NH}_{4} \mathrm{NO}_{3}$ and $\mathrm{NH}_{4} \mathrm{Cl}$ (in which $\mathrm{H}^{+}$is released), $\mathrm{pH}$ markedly decreased to $\mathrm{pH} 3$ and $\mathrm{RG}$ medium de-colorized (Fig. 6). The inoculation with B510 did not significantly affect $\mathrm{pH}$ (Table S2). These results indicate that $\mathrm{NH}_{4}^{+}$ induced acidification around the rice rhizosphere. Therefore, the low $\mathrm{pH}$ caused by $\mathrm{NH}_{4}{ }^{+}$may inhibit endophytic colonization by $\mathrm{B} 510$.

To analyze the effects of $\mathrm{NH}_{4}{ }^{+}$-induced acidification on endophytic colonization by B510, we tested the addition of MES buffer to RG medium, which was expected to prevent a decrease in $\mathrm{pH}$. Without MES buffer, the $\mathrm{pH}$ of RG medium containing $\mathrm{NH}_{4} \mathrm{Cl}$ decreased to 3.4 (Fig. 6). In $\mathrm{RG}$ medium containing $\mathrm{NH}_{4} \mathrm{Cl}$ and $\mathrm{MES}$, pH was maintained at 5.5 (Fig. 6 ) and endophytic and root surface colonization by B510 was not inhibited under higher concentrations of $\mathrm{NH}_{4}{ }^{+}$tested (Fig. 1 and $2 \mathrm{E}$ ). Furthermore, the accumulation of $\mathrm{H}_{2} \mathrm{O}_{2}$ decreased in rice roots grown with $\mathrm{NH}_{4} \mathrm{Cl}$ and $\mathrm{MES}$ (Fig. 3). A chemotactic response by $\mathrm{B} 510$ was observed with exudates extracted from roots grown with $\mathrm{NH}_{4} \mathrm{Cl}$ and MES (Fig. 4). In addition, malic acid secretion was increased by the B510 inoculation in exudates from roots grown with $\mathrm{NH}_{4} \mathrm{Cl}$ and MES (Fig. 5). These results indicate that the $\mathrm{pH}$ decrease induced by $\mathrm{NH}_{4}^{+}$ inhibited endophytic colonization by B510. We then performed a bacterial growth test using NB media adjusted to different $\mathrm{pH}$ levels ( $\mathrm{pH} 3-8)$. The results obtained indicated that acidic media with $\mathrm{pH}<4$ suppressed the growth of B510 (Table S4). These results imply that acidification directly affects the bacterial growth of as well as endophytic colonization by B510.

\section{Discussion}

Endophytic bacteria invade internal plant tissues through sites of injury in the epidermis, root tips, and root cracks formed at the sites of lateral roots, and some endophytic bacteria spread to distant plant organs $(5,36)$. Azospirillum $\mathrm{sp}$. B510 was isolated from the stems of rice (13). A previous study demonstrated that B510 colonized the interior of rice roots using orthogonal optical sections (7). In the present 
study, we observed strong red fluorescence around lateral root emergence sites by fluorescence microscopy using DsRed-labeled B510, suggesting that Azospirillum sp. B510 invades through this site and then spreads to stems and leaves (Fig. 1). We did not detect any surface colonization by B510 in the roots under high $\mathrm{NH}_{4}{ }^{+}$concentrations (Fig. 1). The fluorescence of DsRed is known to decrease under mildly acidic conditions (pH 4.0-4.8) (39). In our experiments, high concentrations of $\mathrm{NH}_{4}{ }^{+}$acidified the rhizosphere to a $\mathrm{pH}$ of 3.0-3.9, suggesting the quenching of DsRed under acidic conditions. Consequently, we confirmed decreased colonization by B510 on root surfaces from plants grown with $\mathrm{NH}_{4}{ }^{+}$concentrations higher than $1 \mathrm{mM}$ using a plate dilution method (Fig. S1).

A microscopic analysis also showed the non-uniformity of colonization by B510 on the root surface (Fig. 1). A previous study on non-uniform colonization by endophytic bacteria used the term 'carpet-like structure' to describe its appearance (44). This appearance may be explained by numerous factors, such as various root exudation patterns and bacterial quorum sensing effects, as well as chemotactic responses, twitching motility, exopolysaccharide production, and ROSscavenging enzymes (1, 4, 8, 29). Moreover, Azospirillum spp. exhibit strain-specific chemotactic responses to organic acids (33). In B510, we observed a chemotactic response to rice root exudates and organic acids, and plants inoculated with B510 secreted more chemotactic compounds than non-inoculated plants (Fig. 4, 5). This strain strongly responds to oxalic acid (Fig. S3h). The different chemotactic responses among strains has been linked to the adaptation of the bacteria to the nutrient conditions provided by the host plants (33).

Biofilms or EPS have great importance in plant microbe interaction. Biofilm integration of bacterial cells convert or adapt their habitat by generating extracellular polymeric substance (EPS) matrix, reduced growth rates, regulate the quorum sensing and the up- and down regulation of specific genes. B510 produced EPS at similar levels regardless of the nitrogen source $\left(\mathrm{NH}_{4}^{+}\right.$or $\mathrm{NO}_{3}$; Fig. S4). This suggests that EPS-mediated attachment may not be a key step in the $\mathrm{NH}_{4}{ }^{+}$ dependent suppression of colonization. Our results suggest that B510 in the soil moves towards the host plant, and after stable colonization using EPS, induces host plants to increase their secretion of compounds such as organic acids, which the bacteria then use for their growth.

Rice plants need large amounts of nitrogen, especially for growth of above-ground tissues, such as leaves. Generally, chemical fertilizers such as $\mathrm{NO}_{3}^{-}, \mathrm{NH}_{4}{ }^{+}$, or urea are applied directly to the plant roots in order to maximize absorption. Rice plants have the capacity to utilize both $\mathrm{NO}_{3}{ }^{-}$and $\mathrm{NH}_{4}{ }^{+}$ $(24,26)$. Although the growth of above-ground rice tissues is similar with the application of either $\mathrm{NO}_{3}{ }^{-}$or $\mathrm{NH}_{4}{ }^{+}$, in our study, the growth of roots is suppressed dramatically by high concentrations of $\mathrm{NH}_{4}^{+}$(Fig. S2). As shown in Fig. S2, plant growth suppression by B510-inoculation was observed under some conditions. Previous studies reported that B510 enhanced rice growth and yield (21), however, the positive effects of B510 were dependent on the plant growth condition. Sasaki et al. (2010) showed the negative effects of B510 on rice cv. Nipponbare underin a low nitrogen fertilizer-applied field (37). Since RG medium does not contain many nutrients, the
B510 inoculation may induce stress in rice plants by competing for nutrients. Moreover, the B510 inoculation caused root tip curling (shown in Fig. 3). This morphological change may also cause the growth suppression of rice plants.

B510 did not grow under acidic conditions $(\mathrm{pH}<4)$, suggesting that rhizosphere acidification by $\mathrm{NH}_{4}{ }^{+}$contributes to the inhibition of bacterial colonization. Plants maintain a neutral intracellular $\mathrm{pH}$ ( $\mathrm{pH}$ 6-7) even when the rhizosphere is acidic $(25,32)$. However, in the present study, endophytic colonization by B510 was not observed when the rhizosphere was acidic. This result suggests that B510 resides in the intercellular spaces of host roots rather than intracellularly and, thus, bacterial infection is affected by extracellular $\mathrm{pH}$ changes. The optimal $\mathrm{pH}$ for the growth of $\mathrm{B} 510$ is $\mathrm{pH} 5-7$, as is that of other Azospirillum sp. strains (Table S4; [12]).

Host-derived ROS are key factors controlling the bacterial infection of host plants. Endophytic bacteria possess ROSscavenging enzymes to allow successful infection. Genome data shows that B510 has two superoxide dismutases ( $\operatorname{sod} 1$ : AZL 024870, sod2: AZL 014560) and a glutathione reductase (NADPH: AZL_a04110). These two enzymes are essential for endophytic colonization by Gluconacetobacter diazotrophicus PAL5 (1). In the present study, rice plants constitutively produced the ROS, $\mathrm{H}_{2} \mathrm{O}_{2}$, at higher levels under high $\mathrm{NH}_{4}{ }^{+}$ concentrations (Fig. 3). This result implies that B510 overcomes transient and low-level ROS production by the host plant using these types of ROS-scavenging enzymes, but also that it cannot overcome constitutive and high-level ROS production by the host under high $\mathrm{NH}_{4}^{+}$concentrations. However, the accumulation of $\mathrm{H}_{2} \mathrm{O}_{2}$ was significantly decreased in rice roots grown with $\mathrm{NH}_{4} \mathrm{Cl}$ and MES (Fig. 3), and endophytic colonization by $\mathrm{B} 510$ was not suppressed in these rice roots. These results suggest that high $\mathrm{NH}_{4}{ }^{+}$concentrations inhibit colonization by B510 not only through acidification, but also with the accumulation of high levels of ROS production.

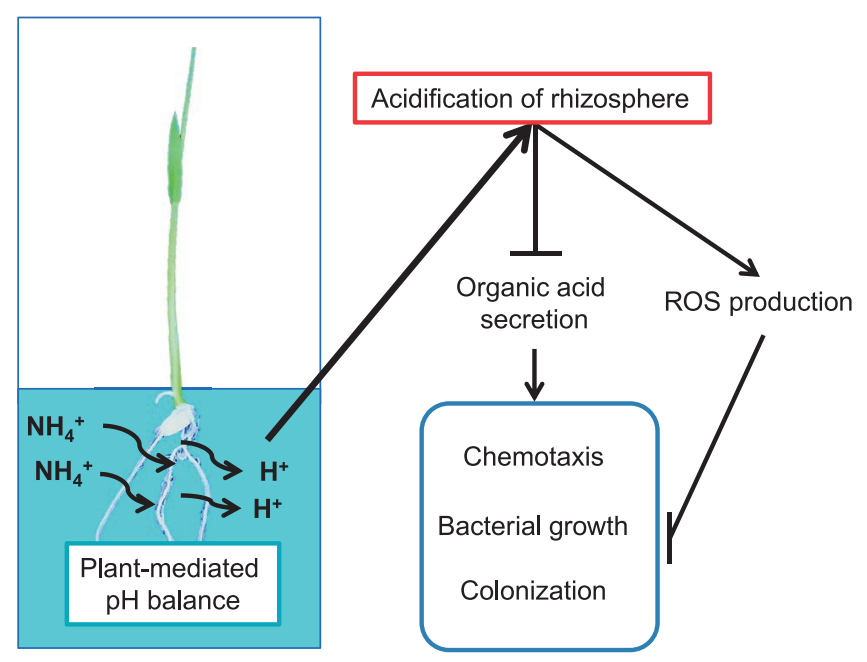

Fig. 7. Proposed model for the suppression of bacterial colonization of rice roots by acidification with $\mathrm{NH}_{4}^{+}$

Following the application of $\mathrm{NH}_{4}^{+}$, rice plants induce a $\mathrm{H}^{+}$efflux to maintain the $\mathrm{pH}$ inside their cells. The consequent acidification of the rhizosphere suppresses the secretion of chemotactic substrates, including malic acid, by the roots. As a result, the growth of bacteria, such as B510, is markedly suppressed. Moreover, acidification induces the production of ROS, including $\mathrm{H}_{2} \mathrm{O}_{2}$, by the plant roots. This suppresses colonization by endophytic bacteria, such as B510. 
In the present study, we demonstrated that high concentrations of $\mathrm{NH}_{4}{ }^{+}$inhibited the endophytic colonization of rice by B510. We propose a model to explain the mechanisms by which this phenomenon occurs (Fig. 7). In this model, rootmediated $\mathrm{pH}$ changes, caused by the application of $\mathrm{NH}_{4}^{+}$, result in acidification around the rice rhizosphere. Low $\mathrm{pH}$ $(<5.0)$ decreases root growth, increases $\mathrm{H}_{2} \mathrm{O}_{2}$ accumulation (45), and inhibits the secretion of chemotactic organic acids in root exudates, thereby suppressing the growth of and colonization by this bacterium. $\mathrm{H}_{2} \mathrm{O}_{2}$ production is reduced in plants grown in the presence of $\mathrm{NH}_{4}^{+}$and inoculated with $\mathrm{B} 510$ (Fig. 3). The biosynthesis of malic acid was increased in plants grown in the presence of $\mathrm{NO}_{3}{ }^{-}$and inoculated with $\mathrm{B} 510$ (Fig. 5 ), and their root exudates exhibited enhanced chemotactic activity (Fig. 4). This result indicates additional benefits to those identified in previous studies, in which B510 enhanced plant growth and plant disease resistance $(21,42)$. These beneficial traits make B510 a superb source of biofertilizer.

Recent studies reported that rice plants fertilized with nitrogen contribute to environmental pollution (such as eutrophication) by emitting ammonia in Japanese rice paddies, which is caused by $\mathrm{NH}_{4}^{+}(16,17)$. In the present study, endophytic B510 cells were maintained at high numbers by controlling the $\mathrm{pH}$ of the rice rhizosphere using a buffer, and the roots also secreted more chemotactic compounds. Future studies will be directed towards the identification of the optimal combination of nitrogen fertilizers and B510 inoculation to promote the sustainable production of crops such as rice.

\section{Acknowledgements}

We thank Drs. Tetsuya Chujo and Tsuyoshi Isawa (Mayekawa Co., Japan) for kindly providing Azospirillum sp. B510 and critical comments. We thank Prof. Hiroshi Kouchi (International Christian University, Japan) for kindly providing the plasmid pBjGroEL4::dsRed2 and critical comments. We thank Prof. Naoko Ohtsu (Tokyo University of Agriculture and Technology) for technical support. We thank Ms. S. Ueda (Woman Support Center, Tokyo University of Agriculture and Technology) for technical support.

\section{Funding}

This work was supported by the Japan Society for the Promotion of Science [26.40133 to M.Y. and 25450082 to S.O.]. This work was supported by Special Coordination Funds for Promoting Science and Technology; PROBRAIN; Mayekawa MFG. Co., Ltd..

\section{References}

1. Alqueres, S., C. Meneses, L. Rouws, M. Rothballer, I. Baldani, M. Schmid, and A. Hartmann. 2013. The Bacterial superoxide dismutase and glutathione reductase are crucial for endophytic colonization of rice roots by Gluconacetobacter diazotrophicus PAL5. Mol. Plant Microbe Interact. 26:937-945.

2. Bashan, Y., and L.E. de-Bashan. 2010. How the plant growth-promoting bacterium Azospirillum promotes plant growth-a critical assessment. Adv. Agron. 108:77-136.

3. Bédard, C., and R. Knowles. 1989. Physiology, biochemistry, and specific inhibitors of $\mathrm{CH}_{4}, \mathrm{NH}_{4}^{+}$, and $\mathrm{CO}$ oxidation by methanotrophs and nitrifiers. Microbiol. Rev. 53:68-84.

4. Böhm, M., T. Hurek, and B. Reinhold-Hurek. 2007. Twitching motility is essential for endophytic rice colonization by the $\mathrm{N}_{2}$-fixing endophyte Azoarcus sp. strain BH72. Mol. Plant Microbe Interact. 20:526-533.
5. Carvalho, T.L.G., E. Balsemão-Pires, R.M. Saraiva, P.C.G. Ferreira, and A.S. Hemerly. 2014. Nitrogen signalling in plant interactions with associative and endophytic diazotrophic bacteria. J. Exp. Bot. 65:5631-5642.

6. Cassán, F., and M. Diaz-Zorita. 2016. Azospirillum sp in current agriculture: From the laboratory to the field. Soil Biol. Biochem. 103:117-130.

7. Chamam, A., H. Sanguin, F. Bellvert, G. Meiffren, G. Comte, F. Wisniewski-Dyé, C. Bertrand, and C. Prigent-Combaret. 2013. Plant secondary metabolite profiling evidences strain-dependent effect in the Azospirillum-Oryza sativa association. Phytochemistry 87:65-77.

8. Compant, S., C. Clément, and A. Sessitsch. 2010. Plant growth-promoting bacteria in the rhizo- and endosphere of plants: Their role, colonization, mechanisms involved and prospects for utilization. Soil Biol. Biochem. 42:669-678.

9. Crawford, N.M., and B.G. Forde. 2002. Molecular and developmental biology of inorganic nitrogen nutrition. Arabidopsis Book. 1:e0011.

10. de Weert, S., H. Vermeiren, I.H. Mulders, I. Kuiper, N. Hendrickx, G.V. Bloemberg, J. Vanderleyden, R. De Mot, and B.J. Lugtenberg. 2002. Flagella-driven chemotaxis towards exudate components is an important trait for tomato root colonization by Pseudomonas fluorescens. Mol. Plant Microbe Interact. 15:1173-1180.

11. Donlan, R.M. 2002. Biofilms: Microbial Life on Surfaces. Emerg. Infect. Dis. 8:881-890.

12. Eckert, B., O.B. Weber, G. Kirchhof, A. Halbritter, M. Stoffels, and A. Hartmann. 2001. Azospirillum doebereinerae sp nov., a nitrogenfixing bacterium associated with the C4-grass Miscanthus. Int. J. Syst. Evol. Microbiol. 51:17-26.

13. Elbeltagy, A., K. Nishioka, T. Sato, H. Suzuki, B. Ye, T. Hamada, T. Isawa, H. Mitsui, and K. Minamisawa. 2001. Endophytic colonization and in planta nitrogen fixation by a Herbaspirillum sp isolated from wild rice species. Appl. Environ. Microbiol. 67:5285-5293.

14. Fallik, E., and Y. Okon. 1996. Inoculants of Azospirillum brasilense: Biomass production, survival and growth promotion of Setaria italica and Zea mays. Soil Biol. Biochem. 28:123-126.

15. Fester, T., and G. Hause. 2005. Accumulation of reactive oxygen species in arbuscular mycorrhizal roots. Mycorrhiza 15:373-379.

16. Hayashi, K., S. Nishimura, and K. Yagi. 2006. Ammonia volatilization from the surface of a Japanese paddy field during rice cultivation. Soil Sci. Plant Nutr. 52:545-555.

17. Hayashi, K., S. Nishimura, and K. Yagi. 2008. Ammonia volatilization from a paddy field following applications of urea: Rice plants are both an absorber and an emitter for atmospheric ammonia. Sci. Total Environ. 390:485-494.

18. Hayashi, M., S. Shiro, H. Kanamori, et al. 2014. A thaumatin-like protein, Rj4, controls nodule symbiotic specificity in soybean. Plant Cell Physiol. 55:1679-1689.

19. Heulin, T., A. Guckert, and J. Balandreau. 1987. Stimulation of root exudation of rice seedlings by Azospirillum strains: carbon budget under gnotobiotic conditions. Biol. Fertil. Soils 4:9-14.

20. Hinsinger, P., C. Plassard, C. Tang, and B. Jaillard. 2003. Origins of root-mediated $\mathrm{pH}$ changes in the rhizosphere and their responses to environmental constraints: A review. Plant Soil 248:43-59.

21. Isawa, T., M. Yasuda, H. Awazaki, K. Minamisawa, S. Shinozaki, and H. Nakashita. 2010. Azospirillum sp strain B510 enhances rice growth and yield. Microbes Environ. 25:58-61.

22. Janzen, R.A., S.B. Rood, J.F. Dormaar, and W.B. Mcgill. 1992. Azospirillum brasilense produces gibberellin in pure culture on chemically-defined medium and in co-culture on straw. Soil Biol. Biochem. 24:1061-1064.

23. Kaneko, T., K. Minamisawa, T. Isawa, et al. 2010. Complete genomic structure of the cultivated rice endophyte Azospirillum sp B510. DNA Res. 17:37-50.

24. Kirk, G.J.D. 2001. Plant-mediated processess to acquire nutrients: nitrogen uptake by rice plants. Plant Soil 232:129-134.

25. Kosegarten, H., F. Grolig, J. Wieneke, G. Wilson, and B. Hoffmann. 1997. Differential ammonia-elicited changes of cytosolic $\mathrm{pH}$ in root hair cells of rice and maize as monitored by 2',7'-bis-(2-carboxyethyl)-5 (and -6)-carboxyfluorescein-fluorescence ratio. Plant Physiol. 113:451461.

26. Kronzucker, H., M.Y. Siddiqi, A.D.M. Glass, and G.J.D. Kirk. 1999. Nitrate-ammonium synergism in rice. A subcellular flux analysis. Plant Physiol. 119:1041-1045. 
27. Le Bot, J., D.J. Pilbeam, and E.A. Kirkby. 1994. Plant mineral nutrition in crop production, p. 33-72. In A.S. Basra (ed.), Mechanisms of Plant Growth and Improved Productivity, Marcel Dekker Inc., New York.

28. Lin, W., Y. Okon, and R.W.F. Hardy. 1983. Enhanced mineral uptake by zea-mays and sorghum-bicolor roots inoculated with Azospirillumbrasilense. Appl. Environ. Microbiol. 45:1775-1779.

29. Liu, P.V., and H.C. Hsieh. 1969. Inhibition of protease production of various bacteria by ammonium salts: its effect on toxin production and virulence. J. Bacteriol. 99:406-413.

30. Meneses, C.H.S.G., L.F.M. Rouws, J.L. Simões-Araújo, M.S. Vidal, and J.I. Baldani. 2011. Exopolysaccharide production is required for biofilm formation and plant colonization by the nitrogen-fixing endophyte Gluconacetobacter diazotrophicus. Mol. Plant Microbe Interact. 24:1448-1458.

31. Murty, M.G., and J.K. Ladha. 1988. Influence of Azospirillum inoculation of the mineral uptake and growth of rice under hydroponic conditions. Plant Soil 108:281-285.

32. Pittman, J.K. 2012. Multiple transport pathways for mediating intracellular $\mathrm{pH}$ homeostasis: the contribution of $\mathrm{H}+$ /ion exchangers. Front. Plant Sci. 3:11

33. Reinhold, B., T. Hurek, and I. Fendrik. 1985. Strain-specific chemotaxis of Azospirillum spp. J. Bacteriol. 162:190-195.

34. Reynders, L., and K. Vlassak. 1982. Use of Azospirillum brasilense as biofertilizer in intensive wheat cropping. Plant Soil 66:217-223.

35. Rudrappa, T., K.J. Czymmek, P.W. Paré, and H.P. Bais. 2008. Rootsecreted malic acid recruits beneficial soil bacteria. Plant Physiol. 148:1547-1556.

36. Santoyo, G., G. Moreno-Hagelsieb, M.C. Orozco-Mosqueda, and B.R. Glick. 2016. Plant growth-promoting bacterial endophytes. Microbiol. Res. 183:92-99.
37. Sasaki, K., S. Ikeda, S. Eda, et al. 2010. Impact of plant genotype and nitrogen level on rice growth response to inoculation with Azospirillum sp. strain B510 under paddy field conditions. Soil Sci. Plant Nutr. 56:636-644.

38. Vessey, J. 2003. Plant growth promoting rhizobacteria as biofertilizers. Plant Soil 255:571-586.

39. Vrzheshch, P.V., N.A. Akovbian, S.D. Varfolomeyev, and V.V. Verkhusha. 2000. Denaturation and partial renaturation of a tightly tetramerized DsRed protein under mildly acidic conditions. FEBS Lett. 487:203-208.

40. Wilson, C., R. Lukowicz, S. Merchant, et al. 2017. Quantitative and qualitative assessment methods for biofilm growth: A mini-review. Res. Rev.: J. Eng. Technol. 6:1-25.

41. Wu, G., B.J. Shortt, E.B. Lawrence, E.B. Levine, K.C. Fitzsimmons, and D.M. Shah. 1995. Disease resistance conferred by expression of a gene encoding $\mathrm{H}_{2} \mathrm{O}_{2}$-generating glucose oxidase in transgenic potato plants. Plant Cell 7:1357-1368.

42. Yasuda, M., T. Isawa, S. Shinozaki, K. Minamisawa, and H. Nakashita. 2009. Effects of colonization of a bacterial endophyte, Azospirillum sp B510, on disease resistance in rice. Biosci. Biotechnol. Biochem. 73:2595-2599.

43. Yasuda, M., H. Miwa, S. Masuda, Y. Takebayashi, H. Sakakibara, and S. Okazaki. 2016. Effector-triggered immunity determines host genotype-specific incompatibility in Legume-Rhizobium symbiosis. Plant Cell Physiol. 57:1791-1800.

44. Zachow, C., G. Jahanshah, I. de Bruijn, et al. 2015. The novel lipopeptide poaeamide of the endophyte Pseudomonas poae RE star 1-1-14 is involved in pathogen suppression and root colonization. Mol. Plant Microbe Interact. 28:800-810.

45. Zhang, Y.K., D.F. Zhu, Y.P. Zhang, H.Z. Chen, J. Xiang, and X.Q. Lin. 2015. Low pH-induced changes of antioxidant enzyme and ATPase activities in the roots of rice (Oryza sativa L.) seedlings. PLoS One 10:e116971. 